\title{
Isolation and analysis of a protease gene with an ABC transport system in the fish pathogen Yersinia ruckeri: insertional mutagenesis and involvement in virulence
}

\author{
L. Fernández, ${ }^{1}$ P. Secades, ${ }^{1}$ J. R. Lopez, ${ }^{1}$ I. Márquez ${ }^{2}$ and J. A. Guijarro ${ }^{1}$
}

Author for correspondence: J. A. Guijarro. Tel: +34 985104 218. Fax: +34 985103148. e-mail: jaga@sauron.quimica.uniovi.es

\author{
1 Área de Microbiologia, \\ Departamento de Biologia \\ Funcional, Facultad de \\ Medicina, Instituto \\ Universitario de \\ Biotecnologia de Asturias, \\ Universidad de Oviedo, \\ 33006 Oviedo, Spain \\ 2 SERIDA, Laboratorio de \\ Sanidad Animal de Jove, \\ 33299 Gijon, Spain
}

\begin{abstract}
Yersinia ruckeri is a Gram-negative pathogen that causes enteric redmouth disease in salmonids. A gene from $Y$. ruckeri encoding an extracellular protease termed yrp1 (Yersinia ruckeri protease 1) was cloned from a Sau3AI library constructed in pUC19 and analysed in gelatin-supplemented medium. The nucleotide sequence of the yrp1 gene indicated an ORF encoding a protein of $477 \mathrm{aa}$. On the basis of the high degree of homology in the amino acid sequence as well as its conservative motifs, this protein was included within the serralysin metalloendopeptidase subfamily (EC 3.4.24.12). The yrp1 Nterminal sequence showed a 14 aa propeptide followed by a 10 aa sequence identical to the one deduced previously from the $47 \mathrm{kDa}$ purified protease. Additional results demonstrated that the yrp1 gene encodes the $47 \mathrm{kDa}$ protein. In contrast to other Yersinia species, the yrp1 protease is secreted by a type I Gram-negative bacterial ABC exporter protein secretion system composed of three genes termed yrpD, yrpE and yrpF, and a protease inhibitor inh. The development of genetic methods for this species has allowed the exploration of the organization and the putative role of the Yrp1 genetic locus. Thus, site-directed insertion mutations into the yrp1 and the yrpE genes were constructed by the integration of the mobilizable suicide vector pIVET8 containing internal portions of both coding sequences. Complementation studies of those mutants with different loci indicated that they are organized as a single operon. The mutant strains lacked protease activity as well as the Yrp1 protein and, although physiologically similar to the parental strain when growing on nutrient broth medium, they were attenuated in virulence when bacteria were injected intraperitoneally into rainbow trout (Oncorhynchus mykiss). This is the first report of defined mutations in $Y$. ruckeri to show the implication of a factor such as an extracellular protease in pathogenesis.
\end{abstract}

Keywords: enteric redmouth disease, pathogenicity, type I secretion system

\section{INTRODUCTION}

The Gram-negative bacterium Yersinia ruckeri is recognized as the aetiological agent of enteric redmouth disease, a systemic infection of salmonid fish that causes important economic losses worldwide. In spite of this, the precise mechanism of the pathogenesis of this bacterium is not known and studies in this field are scarce. As described by Romalde \& Toranzo (1993), it

The GenBank accession numbers for the sequences reported in this paper are AJ318052 (yrp1) and AJ421517 (yrpDEF and inh). seems clear that extracellular products play a role in the pathogenesis of the bacterium because when injected into fish they lead to the appearance of symptoms related to pathogenicity. Among them, haemolysin, cytotoxin, proteolytic and lipolytic activities have been described (Romalde \& Toranzo, 1993). Furones et al. $(1990,1993)$ have also established a relationship between a heat-sensitive factor present in cell extracts and virulence. Other mechanisms involved in pathogenicity of bacteria, such as iron availability, and several ironregulated outer-membrane proteins have been reported in Y. ruckeri (Davies, 1991; Romalde et al., 1991). 
However, to date, neither of these factors has been confirmed as virulence factors. On the other hand, Romalde et al. (1990) have shown that some properties related to virulence, such as haemagglutination, hydrophobicity and different cell-surface components, are not relevant to the pathogenesis of Y. ruckeri.

The early development of a vaccine in the prevention of this disease is probably one of the reasons why virulence determinants have not been studied in depth. Commercial vaccines for $Y$. ruckeri are composed of formalin-killed whole bacterial cells and they are administered by immersion, providing an effective reduction in mortality (Stevenson, 1997). However, in spite of vaccination, fish farm outbreaks occur from time to time. The micro-organism has been found in the intestinal lining of fish (Busch \& Lingg, 1974) and its presence in carrier fish could be the cause of the appearance of outbreaks under stress conditions (Everlyn, 1996). Thus, it is important to know the pathogenic mechanisms of the bacterium for new approaches to vaccination development, new alternatives or for improving the vaccine.

Proteases have been suggested as one of the extracellular factors contributing to the virulence of micro-organisms. In particular, in fish-pathogenic bacteria, indirect experiments have indicated the participation of proteolytic enzymes in pathogenesis (Sakai, 1985; Griffin, 1987; Bertolini et al., 1994; Gunnlaugsdottir \& Gudmundsdottir, 1997; Denkin \& Nelson, 1999; Secades et al., 2001). In addition, genetic approaches, such as the truncation of the encoding proteolytic genes, have shown that, although not as a general rule, proteolytic enzymes are involved in the virulence of fish-pathogenic bacteria (Leung \& Stevenson, 1988; Norqvist et al., 1990; Milton et al., 1992; Cascón et al., 2000b). Although their role in pathogenesis is not clear, it seems that colonization and invasion could be one of their major mechanisms of action during host-pathogen interaction, at the same time providing nutrients for the micro-organisms. Thus, enzymes degrading connective and muscular tissues, such as collagenases, elastases, gelatinases, etc., may play a relevant role in pathogenesis.

In Y. ruckeri, extracellular proteolytic activity has been related to virulence (Romalde \& Toranzo, 1993; Secades \& Guijarro, 1999). A $47 \mathrm{kDa}$ extracellular protease from Y. ruckeri has been purified and characterized (Secades \& Guijarro, 1999). We became interested in further characterizing this proteolytic activity and we cloned the gene encoding the $47 \mathrm{kDa}$ protease (Yrp1) of Y. ruckeri 150 and tested its role in virulence. The amino acid sequence of Yrp1 showed the absence of an Nterminal signal sequence and a high degree of homology with metalloproteases of several pathogenic bacteria, particularly with PrtA (Ghigo \& Wandersman, 1992a), PrtC (Dahler et al., 1990) and PrtG (Ghigo \& Wandersman, 1992b) proteases from Erwinia chrysanthemi, the serralysin from Serratia marcescens (Nakahama et al., 1986; Braunagel \& Benedin, 1990) and the metalloproteases from Pseudomonas aeruginosa
(Doug et al., 1992) and Pseudomonas fluorescens (Liao \& McCallus, 1998). The DNA sequence around the yrp1 gene was analysed and a gene cluster homologous to the one found in Erw. chrysanthemi, P. aeruginosa and S. marcescens, described by Binet et al. (1997) and encoding a complete $\mathrm{ABC}$ exporter, was identified and sequenced. Out of the yersiniabactin $\mathrm{ABC}$ components from human-pathogenic Yersinia (Carniel, 1999) and the Yfe and Yfu systems of cation transport found in Yersinia pestis (Bearden \& Perry, 1999; Gong et al., 2001) and Yersinia enterocolitica (Saken et al., 2000), the presence of a haemophore-dependent haem-acquisition system secreted by an ABC transporter system in Y. pestis has recently been reported (Rossi et al., 2001). However, to our knowledge there is no description of an $\mathrm{ABC}$ export protease system in the genus Yersinia. To define the role of the ABC cassette in Yrp1 secretion as well as in the implied role of the protease in pathogenesis, two insertion mutants were generated. We showed, using SDS-PAGE and immunoblot analysis, that the mutants lacked the $47 \mathrm{kDa}$ protein as well as the proteolytic activity using azocasein or gelatin as substrates. The mutants showed a similar growth curve to the parental strain, but $\mathrm{LD}_{50}$ experiments indicated that they were attenuated for rainbow trout. To our knowledge, this is the first time that a protein has been shown to play a role in the pathogenesis of Y.ruckeri.

\section{METHODS}

Bacterial strains, plasmid and culture conditions. The bacterial strains and plasmids used in this work are shown in Table 1. Bacterial strains were routinely cultured on nutrient broth (NB; Difco) at 18 or $28^{\circ} \mathrm{C}$ for Y. ruckeri and $37^{\circ} \mathrm{C}$ for Escherichia coli strains. Growth was monitored by determining $\mathrm{OD}_{600}$ of a culture with a Perkin-Elmer spectrophotometer at different times during incubation at 250 r.p.m. E. coli clones containing proteolytic exocellular activity were selected by using NB medium with $1.5 \%(\mathrm{w} / \mathrm{v}$ ) agar (NA) supplemented with 5 g gelatin $1^{-1}$ (Difco). SDS-PAGE, Western blot analysis and proteolytic activity assays using azocasein as substrate were performed as described by Secades \& Guijarro (1999). When required, X-Gal $\left(0.8 \mathrm{mg} \mathrm{m}^{-1}\right)$, IPTG $\left(1 \mathrm{mg} \mathrm{ml}^{-1}\right)$, ampicillin $\left(100 \mu \mathrm{g} \mathrm{ml}^{-1}\right)$, kanamycin $\left(25 \mu \mathrm{g} \mathrm{ml}^{-1}\right)$ and rifampicin $\left(50 \mu \mathrm{g} \mathrm{ml}^{-1}\right)$ were added to the media.

Nucleic acid preparation and construction and screening of $Y$. ruckeri library. Standard techniques (Sambrook et al., 1989) were used for the construction of recombinant plasmids. DNA fragments were purified from agarose gels using the Qiagen kit (Sigma). DNA restriction enzymes, phage T4 ligase, calf intestinal alkaline phosphatase and oligonucleotides for DNA amplification were purchased from Amersham.

Sequencing grade Taq polymerase (Perkin-Elmer) was employed. Plasmids used in this work were propagated in E. coli strains and isolated by the alkaline lysis method (Birnboim \& Doly, 1979).

DNA from Y. ruckeri 150 was obtained from a $500 \mathrm{ml}$ stationary-phase NB culture by the alkaline method (Sambrook et al., 1989). The DNA was partially digested with Sau3AI and size-fractioned by centrifugation at $215000 \mathrm{~g}$ for $16 \mathrm{~h}$ at $17^{\circ} \mathrm{C}$ into a $10-40 \%$ (v/v) sucrose gradient in TEN buffer $[10 \mathrm{mM}$ Tris $/ \mathrm{HCl}(\mathrm{pH} 8), 1 \mathrm{mM}$ EDTA (pH 8), $100 \mathrm{mM} \mathrm{NaCl}$ ]. Fragments from 5 to $10 \mathrm{~kb}$ were ligated to BamHI-digested and dephosphorylated pUC19 plasmid. The 
Table 1. Bacterial strains and plasmids used in this study

\begin{tabular}{|c|c|c|}
\hline Strain or plasmid & Characteristics & Source or reference \\
\hline \multicolumn{3}{|l|}{ Strains } \\
\hline \multicolumn{3}{|l|}{ Escherichia coli } \\
\hline DH10B & Cloning strain & Pharmacia \\
\hline SM10 $\lambda$ pir & thi thr leu tonA lacY supE recA::RP4-2-Tc:: Mu Km:: $\lambda$ pir & Simon et al. (1983) \\
\hline LPO1/LPO2/LPO3/LPO4 & DH10B with pLPO1, pLPO2, pLPO3 and pLPO4, respectively & This work \\
\hline \multicolumn{3}{|l|}{ Yersinia ruckeri } \\
\hline 150 & Trout isolated virulent strain & Secades \& Guijarro (1999) \\
\hline $150 \mathrm{R}$ & Rif $^{r}$ derivative of 150 & This work \\
\hline 150RI4 & Rif $^{r}$ Yrp1::pIVET8 Ap ${ }^{r} \mathrm{Cm}^{r}$ & This work \\
\hline 150RI6 & Rif $^{r}$ YrE: :pIVET8 Ap $^{r} \mathrm{Cm}^{r}$ & This work \\
\hline \multicolumn{3}{|l|}{ Plasmids } \\
\hline pUC19 & $\mathrm{Ap}^{\mathrm{r}}$, cloning vector & Pharmacia \\
\hline pLPO1 & $\begin{array}{l}8.4 \mathrm{~kb} \text { fragment of Y. ruckeri DNA cloned into pUC19 conferring } \\
\text { protease activity }\end{array}$ & This work \\
\hline pLPO2 & $\begin{array}{l}15.6 \mathrm{~kb} \text { fragment of } Y . \text { ruckeri DNA cloned into pUC19 conferring } \\
\text { protease activity }\end{array}$ & This work \\
\hline pLPO3 & $5 \cdot 1 \mathrm{~kb}$ XbaI fragment from pLPO1 & This work \\
\hline pLPO4 & $3 \cdot 3 \mathrm{~kb}$ Bam HI-XbaI fragment from pLPO1 & This work \\
\hline pIVET8 & $\mathrm{Ap}^{\mathrm{r}}$, suicide vector, $m o b^{+}$, ori $\mathrm{R} 6 \mathrm{~K}$ & Mahan et al. (1995) \\
\hline pLPY1 & pIVET 8::BglII (Yrp1), Ap ${ }^{r}$ & This work \\
\hline pLPY2 & pIVET $8:: B g l$ II (YrpE), Ap ${ }^{r}$ & This work \\
\hline pUK21 & $\mathrm{Km}^{\mathrm{r}}$, pUC-derived cloning vector & Vipond et al. (1998) \\
\hline pUK21B & $\begin{array}{l}2.9 \mathrm{~kb} \text { Bam HI fragment from pLPO1 cloned into pUK } 21 \text { carrying } \\
y r p 1 \text { and inh genes }\end{array}$ & This work \\
\hline pUK21C & $\begin{array}{l}5 \cdot 6 \mathrm{~kb} \text { ClaI fragment from pLPO1 cloned into pUK21 carrying inh, } \\
y r p D, y r p E \text { and } y r p F \text { genes }\end{array}$ & This work \\
\hline PUK21T & $8 \cdot 4 \mathrm{~kb}$ EcoRI-PstI insert from pLPO1 cloned into pUK21 & This work \\
\hline
\end{tabular}

ligated DNA was then used for electroporation of E. coli DH10B strain in a Gene Pulser apparatus (Bio-Rad) set at $2.5 \mathrm{kV}, 25 \mu \mathrm{F}$ and $200 \Omega$. Following electroporation, bacteria were incubated in $1 \mathrm{ml} \mathrm{NB}$ at $37^{\circ} \mathrm{C}$ and 250 r.p.m. for $1 \mathrm{~h}$ without selection and then $E$. coli recombinants were selected by plating the transformed mixture onto NA supplemented with gelatin, ampicillin, X-Gal and IPTG, and incubated for $24 \mathrm{~h}$ at $37^{\circ} \mathrm{C}$. Further incubation for $24 \mathrm{~h}$ at $15^{\circ} \mathrm{C}$ was needed for gelatin hydrolysis visualization.

Subcloning of the yrp1 gene and DNA sequence. An E. coli DH10B clone with an approximately $8.4 \mathrm{~kb} \mathrm{BamHI}$ insert in the pUC19 vector was analysed by fragment subcloning. Synthetic oligonucleotide primers were used to sequence the fragment by the dideoxy chain-termination method, using a DR Terminator Taq FS Sequencing kit (Applied Biosystems). DNA sequence was carried out according to the manufacturer's specifications in an ABI-PRISM 310 A automated DNA sequencer from Perkin-Elmer. Sequencing data were analysed using the BLASTX computer program.

$\mathrm{N}$-terminal amino acid sequencing of the protein. Yrp1 was obtained as described previously (Secades \& Guijarro, 1999). Approximately $25 \mu \mathrm{g}$ of the $47 \mathrm{kDa}$ protein were dialysed against $4110 \mathrm{mM}$ HEPES buffer, $\mathrm{pH} 6 \cdot 8$, concentrated by lyophilization and the $\mathrm{N}$-terminal sequence was determined by automated Edman degradation at the Newcastle University protein sequencing facility. Multiple alignments of protein sequence were generated by using the PILEUP alignment program.
Construction of the derivative plasmids PLPY1 and PLPY2 carrying yrp1 and yrpE internal sequence. The primers used were as follows: forward primers YRPP1 and YRPE1; 5'GCCAAGATCTCATTACAATCTTGGGCA-3' (nt 314-330 in bold type) and 5'-GCCAAGATCTGGGTTGACTGCGCAATA-3' (nt 313-329 in bold type), respectively; reverse primers YRPP2 and YRPE2; 5'-CGTTAGATCTCGCACCATGTAATTCAT-3' (nt 1080-1064 in bold type) and 5'-CGTTAGATCTGTTTCACGGTGCCTTCT-3' (nt 10821098 in bold type), respectively. The primers were used to amplify the 787 and 820 bp internal regions of the yrp 1 and the $y r p E$ genes, respectively. Thermal cycling was conducted with a Perkin-Elmer 9700 GeneAmp thermocycler with an initial denaturation cycle at $94^{\circ} \mathrm{C}$ for $5 \mathrm{~min}$, followed by 25 cycles of amplification (denaturation at $94^{\circ} \mathrm{C}$ for $30 \mathrm{~s}$; annealing at 43 and $47^{\circ} \mathrm{C}$ for $y r p 1$ and $y r p E$, respectively, for $30 \mathrm{~s}$ and extension at $72{ }^{\circ} \mathrm{C}$ for $1 \mathrm{~min}$ ) and a final $7 \mathrm{~min}$ elongation period at $72{ }^{\circ} \mathrm{C}$. The primers contained a $\mathrm{Bg} l \mathrm{II}$ site (underlined) and four additional bases at the $5^{\prime}$ end. The generated amplicons were digested with BglII and the products were ligated with pIVET8 previously digested with the same enzyme. Aliquots of the ligation mixture were used to transform E. coli SM10 ipir by electroporation under the conditions described above. Selection of transformants was performed on NA plates containing ampicillin and plasmid DNA was analysed with restriction endonucleases to identify plasmids carrying the correct inserts. The corresponding clones containing the pLPY1 ('yrp1' insert) and the pLPY2 (' $y r p E$ ' insert) plasmids were then used for conjugation. 
Bacterial conjugation. Conjugation was performed as follows : $250 \mu \mathrm{l}$ of a mid-exponential-growth culture of the donor $E$. coli SM10 $\lambda$ pir strain containing the pLPY1 or the pLPY2 plasmids and $2 \mathrm{ml}$ of the recipient $Y$. ruckeri 150R strain were mixed together in $10 \mathrm{ml}$ distilled water and then filtered through a sterile $0.45 \mu \mathrm{m}$ pore-size filter (Millipore). The filter was placed on an NA plate and incubated at $28^{\circ} \mathrm{C}$ for $6 \mathrm{~h}$, then washed by vortexing with $2 \mathrm{ml} \mathrm{NB}$ and the bacteria were plated onto NA containing gelatin $\left(5 \mathrm{~g} \mathrm{l}^{-1}\right)$, ampicillin $\left(100 \mu \mathrm{g} \mathrm{ml}^{-1}\right)$ and rifampicin $\left(50 \mu \mathrm{g} \mathrm{ml}^{-1}\right)$ and incubated at $28^{\circ} \mathrm{C}$ for 2 days. Following this, plates were transferred to $15^{\circ} \mathrm{C}$ for $24 \mathrm{~h}$ to determine the proteolytic activity on gelatin.

Southern blot analysis. Genomic DNA isolated from Y. ruckeri $150 \mathrm{R}$ and the mutant strains $150 \mathrm{RI} 4$ and $150 \mathrm{RI} 6$ was digested with $\mathrm{BamHI}$ and separated on a $0.6 \%$ (w/v) agarose gel. DNA was transferred to a nylon membrane (Amersham), fixed by UV irradiation and hybridized with the 787 or $820 \mathrm{bp}$ PCR-generated internal fragments from the $y r p 1$ and $y r p E$ genes, respectively, previously purified using the Qiagen kit. Probe labelling, hybridization and developing were performed with the DIG DNA labelling and detection kit from Boehringer Mannheim following the manufacturer's instructions. Prehybridization ( $1 \mathrm{~h}$ ) and hybridization (16 h) were carried out at $68{ }^{\circ} \mathrm{C}$ in $5 \times \mathrm{SSC}, 0.1 \%(\mathrm{w} / \mathrm{v}) \quad \mathrm{N}$-lauroylsarcosine, $0.02 \%$ $(\mathrm{w} / \mathrm{v})$ SDS and $1.5 \%(\mathrm{w} / \mathrm{v})$ kit blocking reagent. Membranes were washed for $1 \mathrm{~h}$ at room temperature and then at $68^{\circ} \mathrm{C}$ for $30 \mathrm{~min}$. Immunological detection was performed using anti-DIG/AP conjugate (1:5000). Membranes were developed until a suitable signal was obtained.

Complementation of mutants. Complementation of mutants was carried out using plasmid pUK21 (Vieira \& Messing, 1991). Three different fragments containing a $2 \cdot 9 \mathrm{~kb}$ Bam HI with the $y r p 1$ and inh genes, a $5.6 \mathrm{~kb} C l a \mathrm{I}$ with the inh, $y r p D$, $y r p E$ and $y r p F$ genes and a $8.4 \mathrm{~kb}$ EcoRI-Pst I with all genes, were ligated into the pUK21 plasmid, generating pUK21B, pUK21C and pUK21T, respectively. Y. ruckeri strains 150RI4 and 150RI6 were transformed by electroporation as described above for E. coli with pUK21B and pUK21C, respectively. Both strains were also transformed with pUK21T. Expression in E. coli DH10B of pUK21T with the $8.4 \mathrm{~kb}$ cloned fragment in both orientations in relation to the lac promoter was also determined. In all cases, the presence of proteolytic activity was analysed by halo production on NA plates containing kanamycin and ampicillin and supplemented with gelatin.

$\mathbf{L D}_{50}$ determination. Rainbow trout (Oncorhynchus mykiss) weighing between 8 and $10 \mathrm{~g}$ were kept on $60 \mathrm{l}$ tanks at $18 \pm 1^{\circ} \mathrm{C}$ in continually flowing dechlorinated water. Groups of 10 fish were challenged by intraperitoneal injection of $0.1 \mathrm{ml}$ serial tenfold dilutions of an exponential-phase culture of bacteria over a range of $10^{2}-10^{6}$ cells. The microorganisms were previously washed and resuspended in PBS. Control fishes were injected with $0.1 \mathrm{ml}$ PBS. The $\mathrm{LD}_{50}$ determinations were calculated according to the method of Reed \& Muench (1938).

\section{RESULTS}

\section{Cloning and sequence analysis of the yrp1 genetic locus}

A library of $Y$. ruckeri 150 DNA was constructed in plasmid pUC19 by sucrose gradient selection of 5-10 kb fragments from partially digested Sau3AI chromosomal DNA. Recombinants that could have proteolytic activity were selected by plating the transformants onto NA

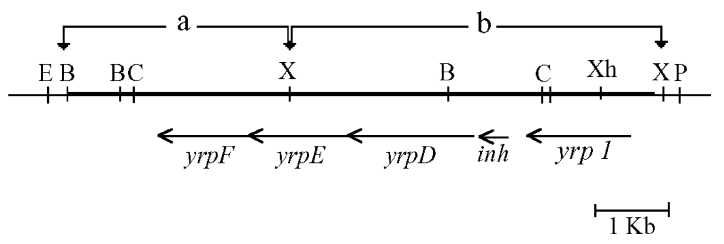

Fig. 1. Restriction map of the recombinant plasmid pLPO1 containing the $Y$. ruckeri 150R Yrp1 gene cluster. The dark line represents the $8.4 \mathrm{~kb}$ Y. ruckeri 150R BamHI-Xbal fragment cloned DNA. The position of each gene and direction of transcription is shown by arrows. Abbreviations: $\mathrm{B}, \mathrm{BamHI}$; C, Clal; X, Xbal; Xh, Xhol; a, $3.3 \mathrm{~kb}$ BamHl-Xbal fragment subcloned into pUC19 to generate plasmid pLPO4; b, $5.1 \mathrm{~kb}$ $X$ bal fragment subcloned into pUC19 to generate plasmid pLPO3. EcoRI (E) and PstI (P) restriction sides flanking the $8.4 \mathrm{~kb}$ DNA fragment are from pUC19.

medium supplemented with ampicillin and gelatin and incubated at $37^{\circ} \mathrm{C}$ for $24 \mathrm{~h}$ and further transferred to $15^{\circ} \mathrm{C}$ for $24 \mathrm{~h}$ to detect gelatin hydrolysis. Two recombinant clones with proteolytic activity were identified. Recombinant plasmid DNAs contained in each one were isolated and used to retransform E. coli DH10B to confirm the proteolytic characteristics of these clones. A restriction map of both recombinant plasmids, pLPO1 and pLPO2, was constructed, showing that they contained the same genomic fragment. Plasmid pLPO1 was used for further studies (Fig. 1). To locate the encoding protease gene, the $5.1 \mathrm{~kb} \mathrm{XbaI}$ fragment from pLPO1 was subcloned into pUC19 to generate plasmid pLPO3 and the remaining plasmid (with a $3.3 \mathrm{~kb} B a m \mathrm{HI}-\mathrm{XbaI}$ insert) was religated to generate pLPO4 (Fig. 1). Both subclones lacked protease activity, suggesting that the central $X b a I$ site was located within the protease-encoding gene. However, when the XbaI $5 \cdot 1 \mathrm{~kb}$ fragment from pLPO3 was sequenced, the $\mathrm{N}$ terminal 10 aa sequence previously determined by Secades \& Guijarro (1999) from the purified $47 \mathrm{kDa}$ metalloprotease of Y. ruckeri 150 (Fig. 1) was found. Further sequencing of this fragment defined the complete yrp1 gene sequence (EMBL accession no. AJ318052). Thus, the yrp1 gene encoding the previously described $47 \mathrm{kDa}$ protease was located at the $5^{\prime}$ end (the right side according to the orientation of the inserted fragment in Fig. 1) of the $5 \cdot 1 \mathrm{~kb} \mathrm{XbaI}$ fragment and the DNA in the central region of the $8.4 \mathrm{~kb}$ fragment was required for halo production in NA gelatin plates. Sequencing of this DNA showed that this region encodes proteins involved in the secretion of the Yrp1 protease. Thus, three ORFs named $y r p D, y r p E$ and $y r p F$ were defined, and an additional coding sequence corresponding to a putative protease inhibitor (inh) was located close to the yrp1 gene (Fig. 1).

The yrp1 sequence contained an ORF of $1431 \mathrm{nt}$, which encoded a polypeptide of $477 \mathrm{aa}$. The deduced molecular mass was $50016 \mathrm{Da}$, which is in good agreement with that observed for the purified metalloprotease (Secades \& Guijarro, 1999). The $\mathrm{pI}$ is 4.46 and the $\mathrm{G}+\mathrm{C}$ content of the yrp1 coding region product is $44.36 \mathrm{~mol} \%$. The 


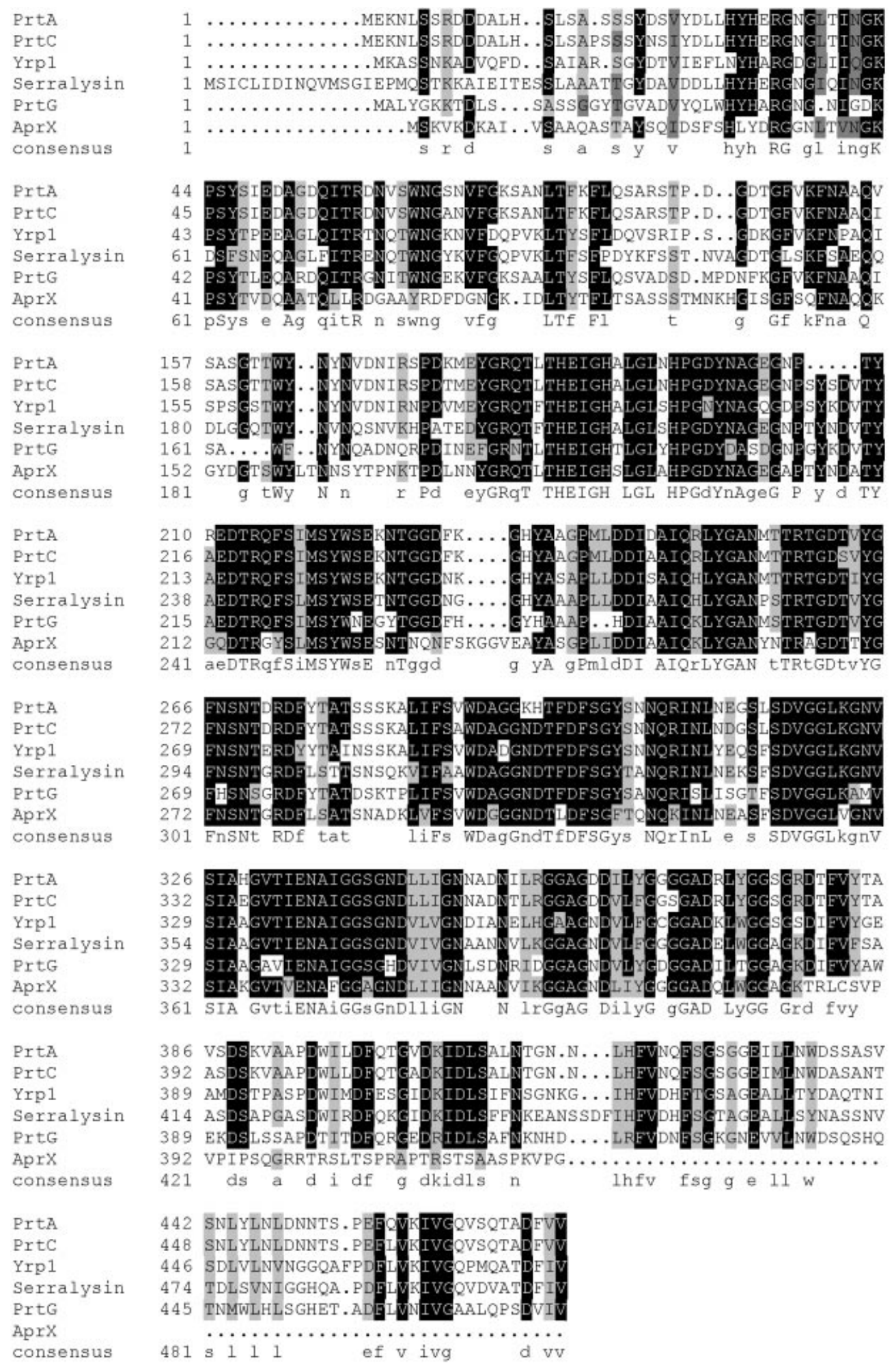

Fig. 2. Amino acid sequence alignment of Yrp1 homologous proteases. PrtA (Ghigo \& Wandersman, 1992a), PrtC (Davies, 1990) and PrtG (Ghigo \& Wandersman, 1992b) correspond with Erw. chrysanthemi proteases; serralysin is a metalloprotease from S. marcescens (Nakahama et al., 1986); AprX corresponds with P. fluorescens metalloprotease (Liao \& McCallus, 1998). A consensus sequence for these metalloproteases is shown. Shaded and grey background boxes correspond to residues identical or similar, respectively, to the consensus sequence. 
Table 2. Characteristics of the deduced yrp genes and Yrp proteins

\begin{tabular}{|lccc|}
\hline Gene & $\begin{array}{c}\text { Gene location } \\
\text { (bp) }\end{array}$ & $\begin{array}{c}\text { No. of aa } \\
\text { residues }\end{array}$ & $\begin{array}{c}\text { Molecular } \\
\text { size (kDa) }\end{array}$ \\
\hline yrp1 & $530-1963$ & 477 & $50 \cdot 02$ \\
inh & $2309-2683$ & 124 & $13 \cdot 33$ \\
yrpD & $2727-4469$ & 580 & $63 \cdot 71$ \\
yrpE & $4496-5827$ & 443 & $49 \cdot 36$ \\
yrpF & $5838-7164$ & 448 & $50 \cdot 75$ \\
\hline
\end{tabular}

predicted amino acid sequence of Yrp1 contains conserved regions such as zinc-binding residues (HEXXH) and two consensus sequences GGXGXD and DXXX at the $\mathrm{C}$ terminus, involved in calcium binding and secretion of the protein by the so-called ABC transmembrane transport proteins secretion pathway, respectively (Binet et al., 1997). The predicted amino acid sequence of the Yrp1 protease also presented a high degree of identity to the PrtA $(66 \%)$ and $\operatorname{PrtC}(67 \%)$ proteases from Erw. chrysanthemi (Dahler et al., 1990; Ghigo \& Wandersman, 1992a), the SM metalloprotease $(64 \%)$ from S. marcescens (Braunagel \& Benedin, 1990) and an alkaline protease $(50 \%)$ from P. fluorescens (Liao \& McCallus, 1998) (Fig. 2). Furthermore, the N-terminal region shows a short sequence of 14 aa homologous to propeptides from these bacterial proteases and the polypeptide is predicted to be cleaved between Ser 14 and Ala 15.

The nucleotide sequence of the remaining $8.4 \mathrm{~kb}$ EcoRIPst I fragment containing the genes involved in the secretion of the protease was analysed. Table 2 shows some of the most interesting characteristics of these genes. The YrpD gene product has six putative transmembrane domains in the N-terminal part and an ATPbinding site in its $\mathrm{C}$-terminal half, corresponding to the putative inner-membrane protein. It has $63 \%$ identity with the prtD gene from Erw. chrysanthemi (Létoffé $e t$ (a)

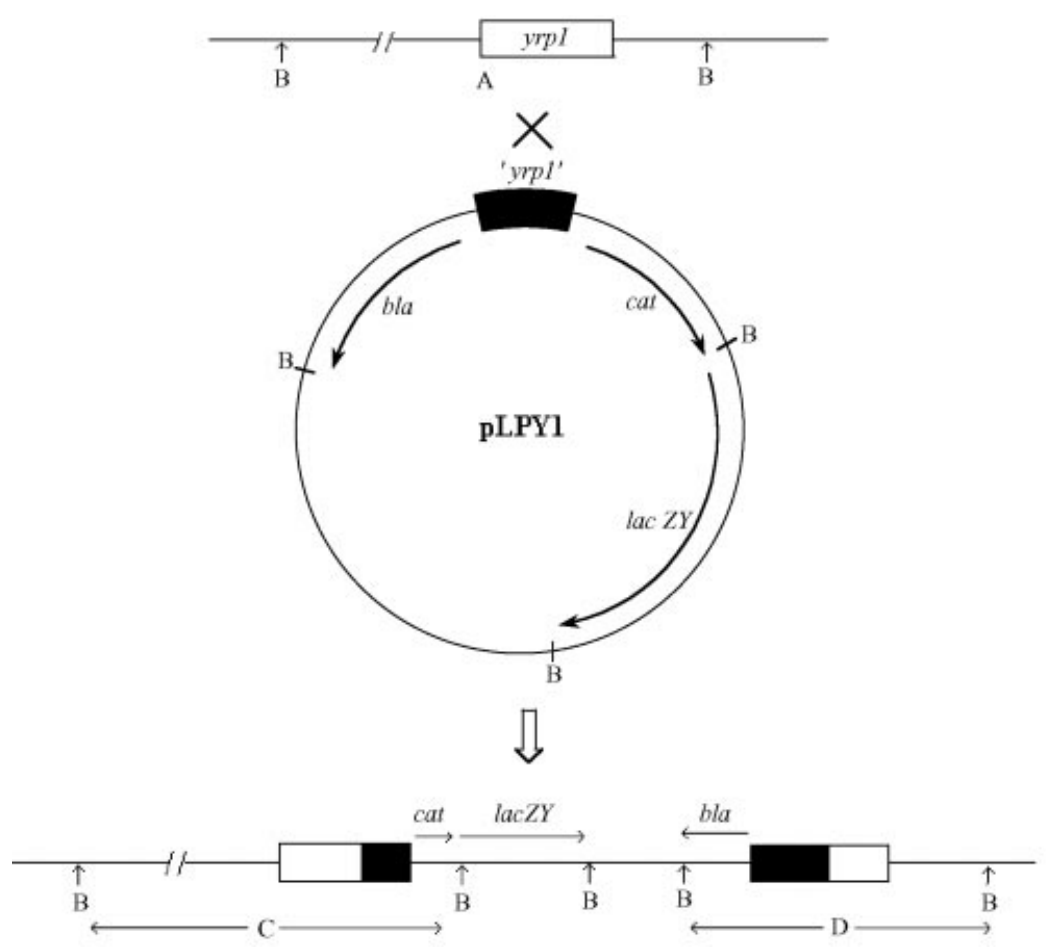

(b)

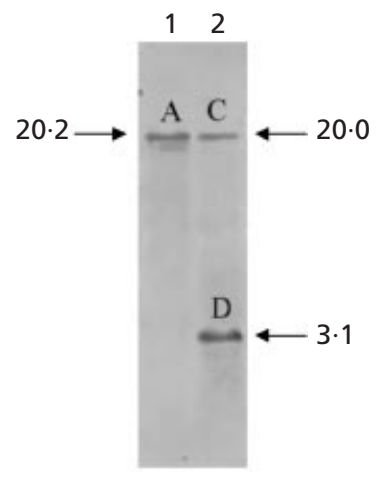

Fig. 3. Construction of $y r p 1$ and $y r p E$ isogenic mutants by insertional mutagenesis. (a) Homologous recombination between the $787 \mathrm{bp}$ yrp1 internal fragment from plasmid pLPY1 and the yrp1 gene from the Y. ruckeri 150R chromosome resulted in insertional mutation of yrp1. Open rectangles, the target yrp1 gene; solid rectangles, the interrupted yrp1 gene. (b) Southern blot analysis of the $Y$. ruckeri 150R mutated strain. Genomic DNA from the parental strain $Y$. ruckeri 150R (lane 1) and mutant strain 150RI4 (lane 2) was digested with BamHI and hybridized with the 787 bp internal yrp1 fragment, previously labelled with digoxigenin as described in Methods. The size of the hybridizing fragments is indicated in kb. B, BamHI; cat, chloramphenicol acetyltransferase gene; lac $Z Y, \beta$-galactosidase and galactoside permease genes; bla, $\beta$-lactamase gene; A, Y. ruckeri 150R 20.2 kb BamHI chromosome fragment flanking the yrp1 gene; C and D, 20.0 and $3.1 \mathrm{~kb} \mathrm{BamHI}$ fragments, respectively, from the Y. ruckeri 150RI4 chromosome containing the yrp1 truncated gene. The construction of the $y r p E$ insertional mutant followed a similar scheme. Homologous recombination between the $820 \mathrm{bp} y r p E$ internal fragment from plasmid $\mathrm{pLPY} 2$ and the $y r p E$ encoding gene from the parental strain chromosome generated an insertion confirmed by Southern blot analysis showing the presence of two BamHI new fragments of 3.5 and $4.3 \mathrm{~kb}$ instead of the $4.7 \mathrm{~kb}$ originated in the parental strain (data not shown). 
al., 1990) and 56 and $55 \%$ identity with the hasD genes from S. marcescens (DDBJ accession no. D83582.1) and P. fluorescens (Idei et al., 1999), respectively. YrpE contains a transmembrane domain located close to the $\mathrm{N}$ terminus, and its amino acid sequence is homologous to the second component of type I secretion pathway. Thus, it shares 57,48 and $47 \%$ identity with the prtE gene from Erw. chrysanthemi (Létoffé et al., 1990) and the metalloprotease secretion proteins from $P$. aeruginosa (Stover et al., 2000) and S. marcescens (DDBJ accession no. D83582.1), respectively. In the same way, the YrpF protein presents a putative signal peptide in the first 21 aa and also shares 63, 52 and 49\% homology with the protease secretion protein from the type I secretion system of Erw. chrysanthemi (Létoffé et al., 1990), P. fluorescens (Idei et al., 1999) and P. aeruginosa (Stover et al., 2000).

\section{Construction, analysis and complementation of $Y$. ruckeri yrp1 and yrpE mutants}

Internal fragments from the $y r p 1$ and the $y r p E$ genes of 787 and $820 \mathrm{bp}$, respectively, were generated by PCR. The oligonucleotides for the PCR amplification were designed in such a way that the generated amplicons had a BglII site at each end. After digestion, the BglII-ended amplicons were introduced by ligation into the single BglII restriction site of the pIVET8 suicide vector, generating the pLPY1 (Fig. 3a) and pLPY2 vectors. The ligation mixtures were electroporated into E. coli SM10 $\lambda$ pir and mobilized into Y. ruckeri $150 \mathrm{R}$ by filter mating. Transconjugant colonies were selected on NA plates supplemented with ampicillin and rifampicin. From these, two strains termed Y. ruckeri 150RI4 and 150RI6 containing insertions in the $y r p 1$ and $y r p E$ genes, respectively, were chosen for further studies (Fig. 3a).

The results of the hybridization analysis using the BglII PCR amplicons as probes and genomic DNA from the parental and mutant strains digested with BamHI enzyme are shown in Fig. 3(b). This digestion produced bands of approximately 3.1 and $20 \mathrm{~kb}$ in the $y r p 1$ mutant strain and 3.5 and $4.3 \mathrm{~kb}$ in the $y r p E$ one (data not shown) when hybridizing with the respective digoxigenin-labelled probes, instead of the 20.2 and $4.7 \mathrm{~kb}$ single fragments that appear, respectively, in the parental strain. Since the pLPY1 and pLPY2 plasmids carry three BamHI sites from the vector pIVET8, these patterns of hybridization show that a disruption of the yrp1 and $y r p E$ genes was obtained by insertion of this vector within the genomic DNA. This result was also confirmed by PCR analysis using oligonucleotides corresponding to the cat gene located in the pIVET8 vector and internal regions of the $y r p 1$ and $y r p E$ genes outside the PCR fragment (data not shown). In conclusion, Southern blotting and PCR analysis of the clones showed that the integration of the suicide vector containing the $y r p 1$ and the $y r p E$ internal fragments into the chromosome had occurred by a single crossover event (Fig. 3a).

The inserted plasmid DNAs were maintained in a stable fashion inside the bacteria when grown in the presence (a)

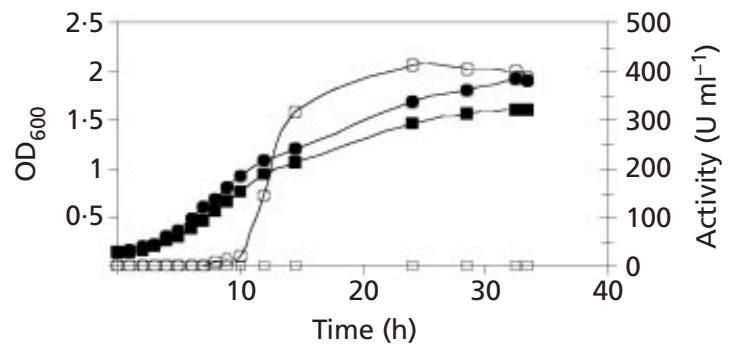

(b)

(c)
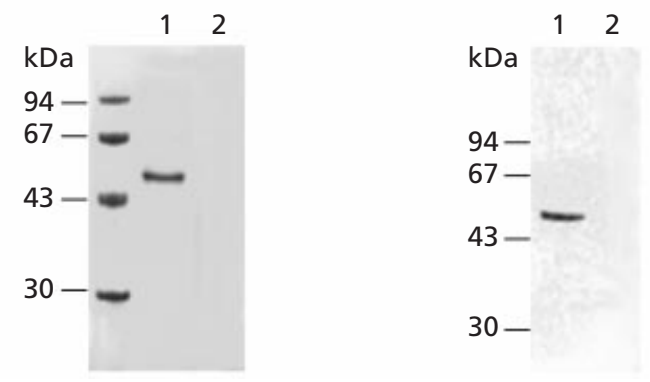

Fig. 4. Growth curve and Yrp1 production analysis of $Y$. ruckeri parental (150R) and mutant (150RI4) strains. (a) The strains were grown in NB, and at different incubation times $120 \mu \mathrm{l}$ of supernatant was used for measuring the proteolytic activity with azocasein as substrate. Y. ruckeri 150R (O) and 150RI4 (ם) growth as determined by $\mathrm{OD}_{600}$. Proteolytic activity of $Y$. ruckeri 150R (O) and 150RI4 ( $\square$ ) strains. (b) SDS-PAGE (12\%) of cell-free supernatants from $Y$. ruckeri 150R (lane 1) and 150RI4 (lane 2) strains. Culture supernatants $(10 \mathrm{ml})$ from $24 \mathrm{~h}$ NBgrown cells were dialysed, freeze-dried and resuspended in $0.25 \mathrm{ml} 25 \mathrm{mM}$ Tris/ $\mathrm{HCl}$ buffer, $\mathrm{pH} 7.6$. Aliquots of $40 \mu \mathrm{l}$ were used for gel loading. After electrophoresis, gels were stained with Coomassie Brilliant Blue R-250. Protein molecular mass markers $(\mathrm{kDa})$ are indicated on the left. (c) Western blot analysis probed with antibodies $(1: 500)$ raised against the $47 \mathrm{kDa}$ protein (Yrp1). Molecular mass markers (kDa) are indicated on the right. Analysis by the same techniques of $Y$. ruckeri 150RI6 produced similar results to the Y. ruckeri 150RI4 mutant. Details are described by Secades \& Guijarro (1999).

or absence of ampicillin as a selection marker. The mutations were also stable after rainbow trout infection experiments, since colonies isolated from the infected fish retained the ampicillin resistance and were devoid of proteolytic activity (data not shown).

As can be observed in Fig. 4a, when parental and yrp1 mutant strains were grown in NB medium at $18^{\circ} \mathrm{C}$, although the mutant showed a slight growth delay, no significant differences were observed in the growth curve. However, when the proteolytic activity of supernatants from both strains was assayed using azocasein as a substrate, no activity at all was found in the $Y$. ruckeri 150RI4 mutant in contrast with the $412 \mathrm{UE} \mathrm{ml}^{-1}$ found in the parental strain (Fig. 4a). On the other hand, when both strains were grown in NB medium and both supernatants were analysed by SDS-PAGE for the presence of the $47 \mathrm{kDa}$ protein, this was only present in the parental Y. ruckeri 150R strain supernatant, but absent in the Y. ruckeri 150RI4 supernatant (Fig. 4b). 
Table 3. Quantitative infection after intraperitoneal inoculation of rainbow trout with the parent (150R) and mutant (150RI4 and 150RI6) strains

\begin{tabular}{|c|c|c|c|c|c|c|}
\hline \multirow{2}{*}{$\begin{array}{l}\text { Bacteria } \\
\left(0 \cdot 1 \mathrm{ml}^{-1}\right)\end{array}$} & \multicolumn{2}{|c|}{ 150RI4 } & \multicolumn{2}{|c|}{ 150RI6 } & \multicolumn{2}{|c|}{$150 \mathrm{R}$} \\
\hline & A & B & A & B & A & B \\
\hline $10^{6}$ & 8 & 9 & 10 & 9 & 9 & 10 \\
\hline $10^{5}$ & 4 & 8 & 8 & 9 & 10 & 10 \\
\hline $10^{4}$ & 0 & 4 & 3 & 3 & 10 & 8 \\
\hline $10^{3}$ & 1 & 4 & 1 & 3 & 8 & 6 \\
\hline $10^{2}$ & 0 & 0 & 2 & 1 & 3 & 4 \\
\hline $\mathrm{LD}_{50}{ }^{*}$ & $1.7 \times 10^{5}$ & $1 \cdot 2 \times 10^{4}$ & $1 \cdot 6 \times 10^{4}$ & $1 \cdot 3 \times 10^{4}$ & $3 \cdot 0 \times 10^{2}$ & $4.6 \times 10^{2}$ \\
\hline
\end{tabular}

$* \mathrm{LD}_{50}$ was calculated for each experiment 7 days after the infection. Columns A and B correspond to dead fish from two independent experiments.

This result was confirmed by immunoblot analysis using antibodies raised against this protein (Fig. 4c). Similar results to that obtained in the Y. ruckeri 150RI4 were found when Y. ruckeri 150RI6 was analysed (data not shown).

To demonstrate that the $y r p D E F$ genes were responsible for the secretion of the Yrp1 protease, the 150RI4 and 150RI6 strains were complemented in trans using plasmids pUK21B, pUK21C and pUK21T. Plasmid pUK21B, carrying the yrp1 and inh genes could not confer protease activity on Y. ruckeri 150RI4, suggesting that the $y r p 1$ insertional mutation produced a polar effect. By contrast, when strain 150RI6 was complemented with the $y r p D E F$ genes on plasmid pUK21C, protease production was obtained. In all cases, the introduction into the insertional mutant strains, in any orientation, of the $8.4 \mathrm{~kb}$ DNA fragment-harbouring plasmid pUK21T produced protease. On the other hand, the synthesis of the Yrp1 protease in E. coli DH10B only took place when the $8.4 \mathrm{~kb}$ fragment containing all five genes was under the control of the lac promoter of pUC19.

\section{Decreased virulence of yrp1 and yrpE mutants}

To determine the effect of the absence of Yrp1 on the virulence of $Y$. ruckeri, the $\mathrm{LD}_{50}$ of three mutant strains was compared with that of the parental strain in a trout model. As little as approximately $10^{2}$ c.f.u. of the wildtype strain resulted in $50 \%$ of the fish dying 7 days after inoculation (Table 3). By contrast, the 150RI4 and 150RI6 mutants presented an $\mathrm{LD}_{50}$ two orders of magnitude higher. Thus, these significant differences between the wild-type and the mutant strains indicate that Yrp1 activity appears to be an important virulence factor.

\section{DISCUSSION}

Despite the importance of Y. ruckeri as a disease agent in salmonid fish farms, the virulence factors and pathogenic mechanisms of this bacterium are practically unknown, although it seems that they are different from those described in other species of the genus. Pathogenesis in Y. ruckeri, as in most pathogens, is probably the result of a cumulative contribution of different secreted and cell-associated virulence factors. We focused our interest on the $47 \mathrm{kDa}$ protease since Romalde \& Toranzo (1993) reported that extracellular product injection into rainbow trout can reproduce many aspects of the pathology observed during infection with $Y$. ruckeri cells. We cloned and sequenced the yrp1 gene encoding a protease and showed that it corresponds with the previously characterized $47 \mathrm{kDa}$ metalloprotease (Secades \& Guijarro, 1999). In addition, the complete cluster of genes involved in protease secretion was also characterized. Two $y r p 1$ and $y r p E$ mutant strains were constructed by insertional mutation, which resulted in attenuated virulence for rainbow trout. Therefore, we have shown for the first time that the protease Yrp1 plays an important role in the pathogenesis of this micro-organism.

The Yrp1 enzyme belongs to the serralysin subfamily of family M12, as defined by Rawlings \& Barrett (1995), having a primary structure very similar to proteases PrtC and PrtA from Erw. chrysanthemi (Dahler et al., 1990; Ghigo \& Wandersman, 1992a), the SM protease from S. marcescens (Braunagel \& Benedin, 1990) and an alkaline metalloprotease from P. fluorescens (Liao \& McCallus, 1998). Thus, amino acid sequences share a percentage of identity between 50 and $67 \%$. The sequence contains the Gly-rich sequences GGXGXD, where $\mathrm{Ca}^{2+}$ is bound, a consensus sequence HEXXH responsible for zinc binding, the zinc ion being an essential component, as well as the 4 aa reported at the end of the C-terminal region involved in some way in the secretion of the protein (Binet et al., 1997). Moreover, the terminal $10 \mathrm{aa}$ of the purified $47 \mathrm{kDa}$ protein matched the deduced N-terminal A15 to V24 amino acid sequence of the $y r p 1$ ORF. This, together with the lack of the $47 \mathrm{kDa}$ protein in the mutant strain shows that the $47 \mathrm{kDa}$ protease previously characterized (Secades \& Guijarro, 1999) is indeed encoded by the yrp1 gene. Enzymic properties of Yrp1 (Secades \& 
Guijarro, 1999) are also similar to the related serralysin proteases. On the other hand, when the yrp1 gene was insertionally truncated, $100 \%$ of the proteolytic activity was lost upon growth in NB medium when azocasein or gelatin was used as enzyme substrate. This might be the only extracellular metalloprotease produced by this bacterium. The yrp1 protease also has a propeptide of 14 aa at the N-terminal end, which should be excised to activate the protease. This suggests that the Yrp1 protein is synthesized and secreted as a zymogen without a signal peptide by an ABC export system, as occurs for the serralysin group of proteases (Binet et al., 1997). Thus, a sequence downstream of the $y r p 1$ gene indicates significant homology with the protease $\mathrm{ABC}$ export systems found in Erwinia, Serratia and Pseudomonas (Binet et al., 1997). With the exception of the yersiniabactins, the Yfu and Yfe cation transporter system and the haemophore system, this type I export system is different from the type III system found in other species of the genus Yersinia (Huek, 1998). The organization of the Y.ruckeri protease production and export system is similar to P. fluorescens, the yrp1 and yrpDEF transporter genes being situated downstream from the $y r p 1$ gene, but different from the systems found in $P$. aeruginosa and Erw. chrysanthemi. This different gene organization among species does not have an obvious evolutionary significance. As expected, the cluster of genes required for the production of extracellular Yrp1 seems to form an operon as indicated by the polar mutation defined by complementation experiments in the 150RI4 mutant. Therefore, the cloned $8.4 \mathrm{~kb}$ DNA fragment contains the regulatory sequence necessary for the expression of the operon in Y. ruckeri according to the protease production obtained when the fragment was introduced in the 150RI4 strain through the pUK21T plasmid in both orientations in relation to the lac promoter.

Differential pathogenicity for Y. ruckeri strains after lethality studies in rainbow trout has been documented (Romalde \& Toranzo, 1993). These differences have been attributed to factors such as adhesive properties (Romalde et al., 1990), protease and haemolytic activities (Romalde \& Toranzo, 1993), iron acquisition systems (Davies, 1991; Romalde \& Toranzo, 1993) and the presence of a heat-sensitive factor (Doug et al., 1992; Everlyn, 1996). However, until now, neither of these factors has been confirmed to be clearly involved in virulence. The present work defines the Yrp1 protease as a virulence factor for $Y$. ruckeri. Thus, when the isogenic 150RI4 and 150RI6 mutants were compared with the parental strain for virulence in intraperitoneally inoculated rainbow trout, the mutants showed a 100 -fold higher $\mathrm{LD}_{50}$. Although a large difference in lethality between the parental and the mutant strains was not obtained, it was significant. As virulence is probably the result of the interaction of a variety of individual factors that, acting together, allow the progression of the infection, this $\mathrm{LD}_{50}$ difference between both strains should be sufficient to consider the involvement of the Yrp1 protease in the progress of infection caused by Y. ruckeri. It must be pointed out that the cells recovered from the infected fish with both mutant strains retained the gelatin-negative phenotype. Different results have been obtained in studies carried out with bacterial proteases from fish pathogens as virulence factors. Thus, in Aeromonas salmonicida, a chemically obtained protease-deficient mutant showed a significant loss in virulence (Sakai, 1985), although Vipond et al. (1998) reported that a strain of $A$. salmonicida carrying a marker replacement of an internal deletion in the serine protease aspA gene was as virulent as the parental strain. In this particular case, this conflicting result could be explained by the fact that in chemically mutated strains, multiple or specific mutations in genes involved in global pathogenesis regulation cannot be excluded. By contrast, in Aeromonas hydrophila, a clear difference has been established by insertion mutation experiments in the implication in virulence of two proteases. Thus, the AhpA serine protease was shown not to be essential for virulence (Cascón et al., 2000a), whereas an elastase was needed for the pathogenesis of the micro-organism (Cascón et al., 2000b). As occurred in Y. ruckeri, the differences in $\mathrm{LD}_{50}$ between the parental and mutant strains were in the order of $10^{2}$. Therefore, according to these results, it seems that a general rule cannot be established about the involvement of exocellular proteolytic enzymes produced by bacteria in fish pathogenesis. Proteolytic enzymes can have a wide range of effects, such as tissue degeneration, invasion, protoxin activation, etc., as well as nutrient acquisition, and probably not all these protease functions are related to virulence, the potential functions of the proteases in vivo being difficult to establish. The present study shows that in Y. ruckeri a metalloprotease is involved in the virulence of the bacterium, although the knowledge of the importance and role of this enzyme in bacterial infection is still to be developed.

\section{ACKNOWLEDGEMENTS}

This work was funded by the FICYT (PB-AGL99-02) and the Spanish DIGICYT (AGL2000-0869). L. Fernández was the recipient of an FPI grant from the Spanish Ministerio de Ciencia y Tecnologia. We thank S. Cal and C. Garabaya for DNA sequencing; J. J. Mekalanos for supplying us with the pIVET8 plasmid; F. Lombó and A. F. Braña for their comments and critical reading of the manuscript. Finally, our thanks to B. Alvarez and A. del Cerro.

\section{REFERENCES}

Bearden, S. W. \& Perry, R. D. (1999). The Yfe system of Yersinia pestis transports iron and manganese is required for full virulence of plague. Mol Microbiol 32, 403-414.

Bertolini, J. M., Wakabayashi, H., Watral, V. G., Whipple, M. J. \& Rohovec, J. S. (1994). Electrophoretic detection of proteases from selected strains of Flexibacter psychrophilus and assessment of their variability. J Aquat Anim Health 6, 224-233.

Binet, R., Létoffé, S., Ghigo, J., Delapelaire, P. \& Wandersman, C. (1997). Protein secretion by gram negative bacteria ABC export: a review. Gene 192, 7-11. 
Birnboim, H. C. \& Doly, J. (1979). A rapid alkaline extraction procedure for screening recombinant plasmid DNA. Nucleic Acids Res 7, 1513-1523.

Braunagel, S. C. \& Benedin, M. S. (1990). The metalloprotease gene of Serratia marcescens strain SM6. Mol Gen Genet 222, 446-451.

Busch, R. A. \& Lingg, A. J. (1974). Establishment of a symptomatic carrier state infection of enteric redmouth disease in rainbow trout (Salmo gairdneri). J Fish Res Board Can 32, 2429-2432.

Carniel, E. (1999). The Yersinia high-pathogenicity island. Int Microbiol 2, 161-167.

Cascón, A., Fregeneda, J., Aller, M., Yugueros, J., Temprano, A., Hernanz, C., Sánchez, M., Rodriguez-Aparicio, L. \& Naharro, G. (2000a). Cloning, characterization, and insertional inactivation of a major extracellular serine protease gene with elastolytic activity from Aeromonas hydrophila. J Fish Dis 23, 1-11.

Cascón, A., Yugueros, J., Temprano, A., Sánchez, M., Hernanz, C., Luengo, J. M. \& Naharro, G. (2000b). A major secreted elastase is essential for pathogenicity of Aeromonas hydrophila. Infect Immun 68, 3233-3241.

Dahler, G. S., Barras, F. \& Keen, N. T. (1990). Cloning of genes encoding extracellular metalloproteases from Erwinia chrysanthemi EC16. J Bacteriol 172, 5803-5815.

Davies, R. L. (1991). Yersinia ruckeri produces four iron-regulated outer membrane proteins but does not produce detectable siderophores. J Fish Dis 14, 563-570.

Denkin, S. M. \& Nelson, D. R. (1999). Induction of protease activity in Vibrio anguillarum by gastrointestinal mucus. Appl Environ Microbiol 65, 3555-3560.

Doug, F., Lazdunski, A., Cami, B. \& Murgier, M. (1992). Sequence of a cluster of genes controlling synthesis and secretion of alkaline protease in Pseudomonas aeruginosa: relationships to other secretory pathways. Gene $121,47-54$.

Everlyn, T. P. T. (1996). Infection and disease. In The Fish Immune System: Organism, Pathogen and Environment, pp. 339-362. Edited by G. Iwana \& T. Nakanishi. San Diego: Academic Press.

Furones, M. D., Gilpin, M. L., Alderman, D. J. \& Munn, C. B. (1990). Virulence of Yersinia ruckeri serotype 1 strains is associated with a heat sensitive factor (HSF) in cell extracts. FEMS Microbiol Lett 66, 339-344.

Furones, M. D., Gilpin, M. L. \& Munn, C. B. (1993). Culture media for the differentiation of isolates of Yersinia ruckeri based on detection of a virulence factor. J Appl Bacteriol 74, 360-366.

Ghigo, J. M. \& Wandersman, C. (1992a). Cloning, nucleotide sequence and characterization of the gene encoding the Erwinia chrysanthemi B374 PrtA metalloprotease: a third metalloprotease secreted via a C-terminal secretion signal. Mol Gen Genet 236, 135-144.

Ghigo, J. M. \& Wandersman, C. (1992b). A fourth metalloprotease gene in Erwinia chrysanthemi. Res Microbiol 143, 857-867.

Gong, S., Bearden, S. W., Geoffroy, V. A., Fetherston, J. D. \& Perry, R. D. (2001). Characterization of the Yersinia pestis $\mathrm{Yfu} \mathrm{ABC}$ inorganic iron transport system. Infect Immun 67, 2829-2837.

Griffin, B. R. (1987). Columnaris disease: recent advances in research. Aquaculture 13, 48-50.

Gunnlaugsdottir, B. \& Gudmundsdottir, B. K. (1997). Pathogenicity of atypical Aeromonas salmonicida in Atlantic salmon compared with protease production. J Appl Microbiol 83, 543-541.

Huek, C. (1998). Type III protein secretion systems in bacterial pathogens in plants and animals. Microbiol Mol Biol Rev 62, 379-433.

Idei, A., Kawai, E., Akatsura, H. \& Omori, H. (1999). Cloning and characterization of the Pseudomonas fluorescens ATP-binding cassette exporter Has DEF, for the heme acquisition protein Has A. J Bacteriol 181, 7545-7551.

Létoffé, S., Delapelaire, P. \& Wandersman, C. (1990). Protease secretion by Erwinia chrysanthemi. EMBO J 9, 1375-1382.

Leung, K. Y. \& Stevenson, R. M. W. (1988). Tn5 induced protease deficient strains of Aeromonas hydrophila with reduced virulence for fish. Infect Immun 56, 2639-2644.

Liao, C. H. \& McCallus, D. E. (1998). Biochemical and genetic characterization of an extracellular protease from Pseudomonas fluorescens CY091. Appl Environ Microbiol 64, 914-921.

Mahan, M. J., Tobias, J. W., Slauch, J. M., Hanna, P. C., Collier, R. J. \& Mekalanos, J. J. (1995). Antibiotic-based selection for bacterial genes that are specifically induced during infection of a host. Proc Natl Acad Sci U S A 92, 669-673.

Milton, D. L., Norquist, A. \& Wolf-Watz, H. (1992). Cloning of a metalloprotease gene involved in the virulence mechanism of Vibrio anguillarum. J Bacteriol 174, 7235-7244.

Nakahama, K., Yoshimura, K., Marumoto, R., Kikuchi, M., Lee, I. S., Hase, T. \& Matsubara, H. (1986). Cloning and sequencing of Serratia protease gene. Nucleic Acids Res 14, 5843-5855.

Norqvist, A., Norrman, B. \& Wolf-Watz, H. (1990). Identification and characterization of a zinc metalloprotease associated with invasion by the fish pathogen Vibrio anguillarum. Infect Immun 58, 3731-3736.

Rawlings, N. D. \& Barrett, A. J. (1995). Evolutionary families of metallopeptidases. Methods Enzymol 248, 183-228.

Reed, L. J. \& Muench, H. (1938). A simple method of estimating fifty percent endpoints. Am J Hyg 27, 493-497.

Romalde, J. L. \& Toranzo, A. E. (1993). Pathological activities of Yersinia ruckeri, the enteric redmouth (ERM) bacterium. FEMS Microbiol Lett 112, 291-300.

Romalde, J. L., Lemos, M. L., Conchas, R. F., Bandín, I. \& Toranzo, A. E. (1990). Adhesive properties and other virulence factors in Yersinia ruckeri. In Pathology in Marine Science, pp. 123-139. Edited by T. C. Cheng \& F. O. Perkins. New York: Academic Press.

Romalde, J. L., Conchas, R. F. \& Toranzo, A. E. (1991). Evidence that Yersinia ruckeri possesses a high affinity iron uptake system. FEMS Microbiol Lett 80, 121-126.

Rossi, M. S., Fetherston, J. D., Létoffé, S., Carniel, E., Perry, R. D. \& Ghigo, J. M. (2001). Identification and characterization of the hemophore-dependent heme acquisition system of Yersinia pestis. Infect Immun 69, 6707-6717.

Sakai, D. K. (1985). Loss of virulence in a protease-deficient mutant of Aeromonas salmonicida. Infect Immun 48, 146-152.

Saken, E., Rakin, A. \& Heesemann, J. (2000). Molecular characterization of a novel siderophore-independent iron transport system in Yersinia. Int J Med Microbiol 290, 51-60.

Sambrook, J., Fritsch, E. F. \& Maniatis, T. (1989). Molecular Cloning: a Laboratory Manual, 2nd edn. Cold Spring Harbor, NY : Cold Spring Harbor Laboratory.

Secades, P. \& Guijarro, J. A. (1999). Purification and characterization of an extracellular protease from the fish pathogen Yersinia ruckeri and effect of culture conditions on production. Appl Environ Microbiol 65, 3969-3975.

Secades, P., Alvarez, B. \& Guijarro, J. A. (2001). Purification and characterization of a psychrophilic calcium induced, growth- 
phase-dependent metalloprotease from the fish pathogen Flavobacterium psychrophilum. Appl Environ Microbiol 67, 24362444.

Simon, R., Priefer, V. \& Puhler, A. (1983). A broad host range mobilization system for in vitro genetic engineering: transposon mutagenesis in Gram negative bacteria. Biotechnology 1, 784-791.

Stevenson, R. M. W. (1997). Immunization with bacterial antigens: yersiniosis. Dev Biol Stand 90, 117-124.

Stover, C. K., Pham, X. Q., Erwin, A. L. \& 23 other authors (2000). Complete genome sequence of Pseudomonas aeruginosa PAO1, an opportunistic pathogen. Nature 406, 954-964.
Vieira, J. \& Messing, J. (1991). New pUC derived cloning vectors with different selectable markers and DNA replication origins. Gene 100, 189-194.

Vipond, R., Bricknell, I. R., Durant, E., Bowden, T. J., Ellis, A. E., Smith, M. \& Maclntyre, S. (1998). Defined deletion mutants demonstrate that the major secreted toxins are not essential for the virulence of Aeromonas salmonicida. Infect Immun 66, 1990-1998.

Received 4 February 2002; accepted 11 March 2002. 